\title{
Charcot-Marie-Tooth disease type 2B2
}

INSERM

\section{Source}

INSERM. (1999). Orphanet: an online rare disease and orphan drug data base. CharcotMarie-Tooth disease type 2B2. ORPHA:101101

Charcot-Marie-Tooth disease, type 2B2 (CMT2B2, also referred to as CMT4C3) is an axonal CMT peripheral sensorimotor polyneuropathy that has been described in a large consanguineous Costa Rican family of Spanish ancestry. 